\title{
MELATIH KREATIVITAS DAN DAYA NALAR SISWA MELALUI MODEL PEMBELAJARAN RME
}

\author{
Mujiasih \\ Dosen Tadris Matematika Fak. Tarbiyah IAIN Walisongo
}

\begin{abstract}
Abstrak
Atas dasar ijin dari Kementerian Pendidikan Nasional, maka model pembelajaran Realistic Mathematics Education (RME) telah dilaksanakan di seluruh Indonesia. Di setiap provinsi, telah ditunjuk beberapa sekolah untuk melaksanakan pembelajaran RME ini. Oleh karena itu, maka mahasiswa Prodi Tadris Matematika perlu disiapkan secara dini, dengan pengetahuan tentang model pembelajaran RME ini, yakni mengetahui sintaks (urutan langkah pembelajaran), dan mampu mempraktikkannya. Dalam pembelajaran matematika di sekolah, ada tiga dimensi utama yang berkaitan dengan pembelajaran matematika di sekolah, yaitu (1) kegunaan matematika dalam kehidupan sehari-hari, (2) matematika sebagai alat berpikir, dan (3) matematika sebagai produk budaya manusia. Pembelajaran matematika harus mampu mengembangkan kemampuan siswa untuk memberikan alasan (reasoning), mengembangkan kreativitas (creativity), daya nalar (think
\end{abstract}


logically), dan pembuktian (proof). Hal ini dapat dicapai melalui pembelajaran RME.

Jadi, pembelajaran matematika di sekolah perlu dijadikan sarana untuk melatih dan mengembangkan kreativitas siswa dalam kapasitasnya sebagai anggota masyarakat yang kelak akan beraktivitas dengan memerlukan kreativitas yang tinggi. Salah satu caranya adalah dengan menerapkan RME (Realistic Mathematics Education) di sekolah.

Kata Kunci: RME, Kreativitas 


\section{PENDAHULUAN}

Dengan adanya ijin dari Kementerian Tadris Nasional, maka model pembelajaran Realistic Mathematics Education (RME) telah dilaksanakan di seluruh Indonesia. Di setiap provinsi, telah ditunjuk beberapa sekolah untuk melaksanakan pembelajaran RME. Di Semarang misalnya, RME telah 4 tahun lebih dilaksanakan yaitu di SD Sekaran 01, SD Petompon 01 dan 03, SD Nurul Islam, dan SD Kristen Petra. Pada tahun-tahun mendatang, tidak menutup kemungkinan RME akan ditumbuhkembangkan semakin luas dan bahkan sampai ke jenjang SMP maupun SMA.

Oleh karena itu, mahasiswa Prodi Tadris Matematika perlu disiapkan sejak dini dengan pengetahuan tentang pembelajaran RME yakni mengetahui sintaks (urutan langkah pembelajaran), dan mampu mempraktikkannya. Dengan demikian, jika kelak mahasiswa Prodi Tadris Matematika sudah menjadi guru dan sekolah tempat mahasiswa tersebut menerapkan RME, maka mahasiswa yang sudah menjadi guru ini tidak akan canggung lagi melaksanakan RME.

Khususnya dalam pembelajaran matematika di sekolah, ada tiga dimensi utama yang berkaitan dengan pembelajaran matematika di sekolah, yaitu: (1) kegunaan matematika dalam kehidupan sehari-hari, (2) matematika sebagai alat berpikir, dan (3) matematika sebagai produk budaya manusia (Josua Sahbandar, 2005:1). Mengetahui dan menghafal semua rumus matematika tentu bukan merupakan tujuan akhir seseorang dalam belajar matematika di sekolah.

Jadi, dari sudut pandang matematika, siswa (peserta didik) telah mengetahui rumus luas daerah segitiga juga bukan merupakan tujuan akhir mempelajari matematika. Dari pandangan bahwa matematika mempunyai kegunaan/manfaat, siswa perlu dilatih untuk melakukan penyelesaian masalah (problem solving) matematika yang terkait dalam kehidupan sehari-hari termasuk dengan cara/algoritma yang non rutin.

Sebagai alat berpikir, pembelajaran matematika harus mampu melatih dan mengembangkan kemampuan siswa untuk memberikan alasan (reasoning), mengembangkan kreativitas 
(creativity), penalaran (think logically) sesuai dengan usia anak, dan pembuktian (proof) untuk anak yang sudah dewasa. Penekanan keempat aspek tersebut amat diperhatikan dalam pembelajaran RME. Guru perlu memberikan porsi yang cukup untuk memunculkan ide dalam mengajarkan matematika melalui berbagai cara untuk meningkatkan daya kreativitas dan daya nalar siswanya melalui kegiatan informal matematika. Sebaiknya, kegiatan informal matematika ini perlu dikaitkan dengan situasi dunia nyata di sekitar siswa (pendekatan realistik).

Hal tersebut juga bersesuaian dengan kata/pendapat ahli Pendidikan matematika dari Belanda penemu model pembelajaran RME (Realistic Mathematics Education), yakni Freudenthal (1991) yang menyatakan "Mathematics must be connected to reality and mathematics as human activity". Matematika harus dikaitkan dengan kehidupan nyata dan matematika sebagai kegiatan manusia. Jadi, pembelajaran matematika juga perlu dijadikan sarana untuk melatih dan mengembangkan kreativitas dan daya nalar siswa dalam kapasitasnya sebagai anggota masyarakat yang jelas akan beraktivitas. Salah satu caranya adalah dengan menerapkan RME di sekolah.

\section{Kreativitas dan Daya Nalar}

Menurut Theodore Levitt (dalam As'ari, 2006:6), dikatakan bahwa "Creativity is thinking up new things. Innovation is doing new things." Selanjutnya dikatakan bahwa ada kendala-kendala yang dapat menghambat daya kreativitas siswa, yakni yang dikenal sebagai Barriers to Creativity (Penghalang Kreativitas). Penghalang Kreativitas tersebut antara lain sebagai berikut.

1. The right answer (guru selalu menuntut pada jawaban yang harus benar).

2. That's not logical (guru menganggap bahwa kegiatan itu tidak logis).

3. Follow the rules (guru menuntut siswa untuk selalu mengikuti semua aturan).

4. Play is frivolous (cara siswa yang beda dianggap sebagai permainan yang tidak keruan). 
5. To err is wrong (menganggap bahwa siswa mencoba-coba adalah salah).

6. I'm not creative (siswa sendiri merasa bahwa dirinya sendiri memang kurang kreatif).

Sedangkan Torrance (1984) mengidentifikasi adanya empat komponen kreativitas : (1) fluency, yaitu kemampuan untuk menghasilkan banyak gagasan (large number of ideas); (2) fleksibilitas, yaitu kemampuan untuk menghasilkan ragam gagasan (variety of ideas); (3) elaborasi, yaitu kemampuan untuk mengembangkan gagasan; dan (4) orisinalitas, yaitu kemampuan menghasilkan gagasan yang tidak biasa.

Kreativitas siswa dalam belajar perlu ditumbuhkembangkan. Pembelajaran yang berbasis kreativitas hendaknya mencerminkan bahwa proses pembelajaran memiliki dasar yang menekankan pada kreativitas siswa yakni membutuhkan struktur tugas yang memfasilitasi proses menghasilkan gagasan dan ragam pemecahan masalah, bukan drilling, pemahaman permukaan, ataupun pembahasan satu jawaban tertentu. Pembelajaran yang banyak ditujukan dan dititikberatkan untuk mengembangkan kreativitas salah satunya adalah model pembelajaran RME (Realistic Mathematics Education). Di Indonesia, RME dikenalkan sebagai Pendidikan Matematika Realistik Indonesia (PMRI).

\section{Model Pembelajaran RME (Realistic Mathematics Education)}

Model ini didasari atas pemikiran Freudenthal (1991) yang menulis "Mathematics must be connected to reality and mathematics as human activity".

Karakteristik dasar dari RME adalah digunakannya konteks nyata untuk dieksplorasi dalam pembelajaran matematika. Pembelajaran matematika yang menggunakan pendekatan RME memandang matematika sebagai aktifitas manusia sehari-hari, sehingga dapat memecahkan masalah kehidupan sehari-hari menjadi bagian yang esensial. Interaksi antar siswa dan siswa dengan guru merupakan hal yang mendasar dalam pendekatan RME. Bentuk-bentuk interaksi tersebut dapat berupa penjelasan 
pembenaran, negosiasi, pertanyaan, atau refleksi interaksi perlu dilakukan secara terus menerus untuk mencapai bentuk formal dari bentuk-bentuk informal siswa. Secara umum lima karakteristik RME diantaranya adalah:

1. Penggunaan konteks real (dikaitkan dengan kehidupan nyata) sebagai titik tolak belajar matematika.

2. Menekankan penyelesaian secara informal sebelum menggunakan cara formal atau menggunakan rumus.

3. Ada upaya mengaitkan sesama topik dalam pelajaran matematika.

4. Menggunakan metode interaktif dalam belajar.

5. Menghargai keberagaman jawaban dan kontribusi siswa.

\section{Penerapan RME di sekolah, sintaksnya sebagai berikut:}

1. Sebelum materi pokok disampaikan, siswa diberikan kegiatan terencana (dapat melalui nyanyian, alat peraga, workshop mini, permainan, atau 1-2 soal kontekstual/realistik) yang mengarahkan agar siswa dapat menemukan atau mengkonstruk pengetahuannya sendiri. Semua kegiatan yang dirancang tersebut dapat dikerjakan oleh para siswa secara informal atau bahkan coba-coba berdasarkan apresiasi atau cara spesifik siswa (karena materi atau algoritma soal/tugas tersebut belum diberikan oleh guru kepada siswa). Pada tahap ini, pengembangan kreativitas (creativity) siswa mulai ditumbuhkembangkan.

2. Guru mengamati/menilai/memeriksa hasil pekerjaan siswa. Guru perlu menghargai keberagaman jawaban siswa.

3. Guru dapat meminta 1 atau 2 siswa untuk mendemonstrasikan temuannya (cara menyelesaikan) di depan kelas. Siswa dilatih untuk mengembangkan kemampuannya dalam memberikan alasan (reasoning).

4. Melalui tanya jawab (sesuai dengan usia anak), guru dapat mengulangi jawaban siswa, agar siswa yang lain memiliki gambaran yang jelas tentang pola pikir siswa yang telah menyelesaikan soal/tugas tersebut. Siswa lain boleh berpendapat beda. 
5. Selanjutnya guru menyampaikan materi pokok pendukung soal/tugas yang baru saja dibahas (atau kegiatan yang baru saja dilakukan), termasuk memberikan informasi tentang algoritma yang tepat untuk menyelesaikan soal atau tugas tersebut.

6. Dengan kegiatan ini, diharapkan para siswa pada akhirnya dapat mengkonstruk pengetahuannya sendiri. Tetapi, guru tetap perlu memberikan arahan secukupnya jika hal itu memang diperlukan.

\section{Strategi Menyelesaikan Kegiatan Informal dalam Pembelaja- ran $\mathrm{RME}$}

Kegiatan informal dalam pembelajaran matematika merupakan sarana yang dimanfaatkan guru untuk melatih siswa dalam mengembangkan daya kreativitas, sehingga jelas penyelesaiannya tidak sederhana. Pada umumnya, penyelesaian tidak menggunakan rumus formal yang diberikan guru di sekolah. Penyelesaian ada yang cenderung dilakukan dengan coba-coba (trial and error), dikaitkan dengan kehidupan nyata, dan menghargai keberagaman jawaban siswa. Tetapi, justru dengan cobacoba dan beraneka ragam cara siswa menyelesaikan tugasnya tersebut, maka diharapkan kreativitas siswa jadi berkembang.

Wono Setya Budhi (2004:1) memberikan kiat berbagai strategi untuk memecahkan masalah matematika yang dikemas dalam bentuk kegiatan informal ini. Strategi tersebut dapat dipakai secara tunggal atau dapat digabungkan. Strategi tersebut adalah sebagai berikut: (1) dapat dengan mengamati polanya, (2) dapat dengan membuat daftar yang teratur, (3) dengan menerka, dan kemudian diuji kembali, (4) dapat dengan membuat tabel, (5) dapat dengan bekerja mundur, (6) dengan mengurai soal dan menyelesaikannya secara bertahap, (7) dapat dengan membuat gambar bantu, (8) dengan menggunakan logika, atau (9) dengan cara membaca soal secara bertahap dan hati-hati.

Pemberian kegiatan informal matematika dalam penerapan RME ini dapat dilakukan di antara kegiatan pembelajaran. Misalnya 15 menit sebelum pelajaran formal dimulai, kepada siswa 
diberi satu/dua soal realistik, workshop, atau melalui permainan matematika, yang penyelesaiannya tidak harus menggunakan rumus matematika formal dari sekolah tetapi penyelesaiannya cenderung menggunakan kekuatan akal/penalaran semata. Dari sini, diharapkan daya kreativitas siswa akan berkembang.

Agar kreativitas berkembang maka ada 4 langkah yang perlu diperhatikan guru. Langkah-langkah tersebut adalah sebagai berikut.

1. Menghargai keberagaman jawaban siswa.

2. erikan kesempatan kepada siswa untuk mengemukakan alasan jawabannya.

3. Berikan tugas/permainan yang bervariasi dan usahakan agar sesuai dengan topik/materi yang sedang/akan diberikan.

4. Berikan kepada siswa waktu yang cukup untuk saling berdiskusi tentang temuannya masing-masing.

\section{Kreativitas sebagai Wahana dalam Berpikir}

Menurut Chuck W. Wiederhold, agar bakat siswa berkembang secara pesat di bidang matematika maka kepada siswa perlu diberikan pelajaran matematika dengan model pembelajaran yang berbasis pada pengembangan kreativitas, sesuai dengan jenjang Pendidikan yang sedang dijalani siswa. Chuck W. Wiederhold (2001:6) selanjutnya menulis bahwa agar dicapai Higher Level Thinking pada diri siswa dalam pelajaran matematika, maka dikatakan bahwa "Higher Level Thinking is concerned with problem finding as well as problem solving, and than shared inquiry, creativity, and think logically." Selanjutnya, Inge Schwank (1993) dalam tulisannya mengatakan bahwa basis esensi matematika adalah aspek kognitif, kreativitas, daya nalar, dan inkuari. Yoshio Kimura (1993:463) menulis bahwa "Creativity is very important in a class because it help student to find theorems by themselves and understand the meaning of deeply"

Karena itu agar ketertinggalan Indonesia dengan negara lain di bidang matematika dapat diperkecil, maka sejak awal perlu dipikirkan langkah berani untuk mendidik siswa di bi- 
dang matematika dengan berbagai cara, yang meliputi penerapan RME berbasis problem solving, inquiry, atau permainan matematika yang menuntut kretivitas. Cara-cara ini akan melatih siswa untuk secara bertahap dapat berpikir tinggi. Dan, berpikir tinggi amat diperlukan dalam belajar matematika dalam jenjang yang lebih tinggi.

Lyn D. English dan Graeme S. Halford (1995:257) bahkan menambahkan bahwa agar siswa terbiasa terlatih kreativitasnya, maka pemecahan masalah dapat ditingkatkan dalam bentuk Problem Posing (siswa mencari dan menemukan tugas/ permainan matematikanya sendiri), sekaligus mampu melatih siswa untuk dapat melakukan mathematical thinking.

Suatu soal yang dapat diangkat sebagai suatu permainan matematika jika:

1. siswa memiliki pengetahuan prasyarat untuk mengerjakan soal tersebut;

2. guru memperkirakan, siswa dapat mengerjakan/menyelesaikan soal tersebut;

3. siswa belum tahu algoritma/prosedur untuk memecahkan soal tersebut;

4. siswa memiliki keinginan untuk memecahkan soal/permainan tersebut.

Selanjutnya, biarkan siswa menemukan sendiri (inquiry) pemecahan soalnya (penyelesaian informalnya) tanpa bantuan yang berlebihan dari guru. Diharapkan, siswa akan memiliki apresiasi yang tinggi dan menumbuhkan ketertarikan terhadap matematika jika mereka benar-benar mengerti tentang penyelesaian kegiatan informal matematika tersebut. Hal ini juga dipertegas oleh Stanley P. Izen (1998:719) bahwa "Students have a much greater appreciation for, and interest in, if they understand by them self." Dengan demikian, RME sebagai model pembelajaran, diharapkan mampu meningkatkan kreativitas siswa-siswa di sekolah. 


\section{Kesimpulan}

Upaya melatih dan mengembangkan kreativitas siswa hendaknya perlu dilakukan sejak dini, salah satunya dengan penerapan model pembelajaran RME, yang sesuai dengan perkembangan intelektual siswa. Untuk dapat menerapkan Pembelajaran RME, maka Mahasiswa Prodi Tadris Matematika sebagai calon guru perlu dibekali pengetahuan yang memadai, agar lebih siap melaksanakan RME.

RME sebagai model pembelajaran memiliki lima karakteristik yaitu (1) Penggunaan konteks real (dikaitkan dengan kehidupan nyata) sebagai titik tolak belajar matematika; (2) Menekankan penyelesaian secara informal sebelum menggunakan cara formal atau menggunakan rumus; (3) Ada upaya mengaitkan sesama topik dalam pelajaran matematika; (4) Menggunakan metode interaktif dalam belajar; dan (5) Menghargai keberagaman jawaban dan kontribusi siswa. 


\section{DAFTAR PUSTAKA}

As'ari. 2006. Mengembalikan Fitrah Kreatif Guru Matematika. Makalah disajikan dalam Seminar Nasional Matematika di UNNES, tanggal 24 Agustus 2006.

Bekti Hermawan Handojo dan Srihari Ediati. 2005. Math Magic. Jakarta: Penerbit PT. Kawan Pustaka.

Brian Bolt. 1990. Permainan dan Teka-Teki Matematika yang Lebih Mengasyikkan. Jakarta: PT. Gramedia.

Chuck W. Wiederhold. 2001. Cooperative Learning \& Higher Level Thinking. San Clemente: Kagan Coperative Learning.

Firmawaty Sutan. 2005. Mahir Matematika Melalui Permainan. Jakarta: Penerbit Puspa Swara.

Freudenthal. 1991. Revisiting Mathematics Education. China Lectures. Dordrecht Kluwer: Academic Publishers.

Inge Schwank. 1993. On the Analysis of Cognitive Structures in Algorithmic Thinking. The Journal of Mathematical Behavior. June 1993. Volume 12, Number 2. New Jersey : Ablex Publishing Corporation. 
Jozua Sahbandar. 2005. Pedoman Penulisan Buku Pelajaran. Jakarta: Departemen Tadris Nasional.

Lyn D. English dan Graeme S. Halford. 1995. Mathematics Education - Models and Processes. Ney Jersey: Lawrence Erlbaum Associates, Publishers.

Max A. Sobel dan Evan M. Maletsky. 2003. Mengajar Matematika. Jakarta: Penerbit Erlangga.

Nasrullah. 1986. Bercengkrama dengan Angka. Bandung: Penerbit Angkasa.

Stanley P. Izen. 1998. Proof in Modern Geometry. Journal of Teachers Mathematics. Volume 91, Number 8, November, p 719.

Wono Setyo Budhi. 2004. Menuju Olimpiade Matematika SMP. Jakarta: PT. Bina Sumber Daya MIPA.

Yoshio Kimura. 1993. Computer Graphics and Mathematics Education. Surabaya : FMIPA IKIP Surabaya. 